\title{
Physiological and Immunological Effects of Rosemary Essential Oil in Growing Rabbit Diets
}

\author{
M. R. El-Gogary ${ }^{1}$, E. A. El-Said ${ }^{2} \&$ A. M. Mansour ${ }^{1}$ \\ ${ }^{1}$ Department of Poultry Production, Faculty of Agriculture, Mansoura University, Mansoura, Egypt \\ ${ }^{2}$ Department of Poultry Production, Faculty of Agriculture, Damietta University, Damietta, Egypt \\ Correspondence: M. R. El-Gogary, Department of Poultry Production, Faculty of Agriculture, Mansoura \\ University, Mansoura, Egypt. E-mail: melgogary@mans.edu.eg
}

Received: March 11, $2018 \quad$ Accepted: April 30, $2018 \quad$ Online Published: June 15, 2018
doi:10.5539/jas.v10n7p485
URL: https://doi.org/10.5539/jas.v10n7p485

\begin{abstract}
The efficacy of rosemary essential oil (REO), as feed additive, on growth and blood constituents of growing New Zealand White (NZW) rabbits was evaluated. Thirty six NZW were distributed into four groups: 1 control and 3 treated groups. The control was fed the basal diet, while feeds of other treatments were fortified with 0.25 , 0.50 and $0.75 \mathrm{~g} / \mathrm{kg}$ REO for groups 2,3 and 4, respectively. The criteria of response were growth performance, carcass traits, blood glucose, plasma lipids, immunoglobulins, total antioxidant capacity (TAC), malondialdehyde (MDA) and testosterone concentrations. Results revealed that REO supplementation had no critical impacts on growth performance, carcass yeild or blood glucose. Rabbits recieving dietary REO exhibited lower lipid profile and higher immunoglobulins A than those of the control. The treated rabbits displayed significantly higher TAC than the basal group with the best reaction for those fed G3 diet. In a similar way, MDA was reduced essentially by including REO. There was a significant increase in testosterone levels due to added REO. The present results indicate that supplemental REO at $0.5 \mathrm{~g} / \mathrm{kg}$ of diet has a beneficial impact on lipid profile, immunity and antioxidant status of rabbits.
\end{abstract}

Keywords: rosemary oil, blood biochemical constituents, immunoglobulins, rabbits

\section{Introduction}

Compared to other types of meats, rabbit meat is high in protein and polyunsaturated fatty acids, and low in calories. In spite of the high content of polyunsaturated fatty acids in rabbit meat is considered a nutritional advantage they make it particularly sensitive to lipid oxidation which can cause loss of the nutritive esteem and discourage physical attributes and tangible nature of meat. Furthermore, lipid oxidation adversely impacts the meat quality as it causes the formation of some toxic compounds and malondialdehyde (MDA). The latter has been exhibited to contrarily influence human's health (Koné et al., 2016; Cardinali et al., 2015). Natural feed addition derived from plants, for example, the essential oils have been suggested as alternative feed supplements in animal production for improving growth performance and the meat quality characteristics (Bento et al., 2013; Simitzis \& Deligeorgis, 2011). In this context, plant extracts have long been utilized for a wide variety of purposes (Jones, 1996). The antimicrobial activity of plant essential oils and extracts are routinely used in many deciplines, including raw and processed food protection, pharmaceuticals, alternative medicine and natural curatives (Lis-Balchin \& Deans, 1997). Much attention has been given by nutritionists to natural antioxidants due to of their correlation with food quality attributes and immunity responses (Cullen et al., 2005). Rosemary (Rosmarinus officinalis L.) is a woody perennial herb native to the Mediterranean area, however currently it is cultivated worldwide as an ornamental and aromatic plant. It became a natural antioxidant because of its phenolic terpenes, as (i.e. rosmarinic acid and rosmarol) with higher antimicrobial properties as well (Cuppett \& Hall, 1998; Peng et al., 2005). The high antioxidant activity of this plant species, as pharmacological consequences, mostly is due to its main chemical components such as: carnosol, caffeic and carnosic acids, rosmarinic and ursolic acids. The antioxidant potential of rosemary essential oil (REO) has been mostly attributed to its main diterpenes, carnosol and carnosic acid, and the essential oil components, as well (Ngo et al., 2011; Rašković et al., 2014). Santana-Méridas et al. (2014) found that the antioxidant-related properties of REO extracts and components are due to its free radical scavenging and anti-lipid peroxidative activity. Essential oils are present in many plant organs and exert different ecological functions depending on their volatile compounds 
complex mixtures that have strong odor (Teixeira et al., 2013). Since, REO exhibited high variations in their anti-oxidant and antimicrobial activities (Moreno et al., 2006). Moreover, Dal Bosco et al. (2005) have reported that rosemary extract supplementation to diet improved carcass color lipid stability in pigeon meat, and in lard (Arouma et al., 1996). Dietary supplementation with rosemary significantly decreased lipid peroxidation, increased reduced glutathione level, and the antioxidant enzymes: peroxidase, glutathione peroxidase, glutathione reductase, glutathione S-transferase and catalase in animals (Sahar et al., 2011). Therefore, this research was designed to evaluate the beneficial effect(s) of dietary REO on performance, blood biochemical and immune responses of growing NZW rabbits.

\section{Experimental Procedures}

This investigation was done at the rabbitary farm, Faculty of Agriculture, Mansoura University, Egypt. A total of $36 \mathrm{NZW}$ weaned male rabbits ( $7 \mathrm{Wk}$ old and $954 \pm 19.5 \mathrm{~g}$ initial body weight) were randomly divided into four equal groups of nine growing rabbits in three replicates, 3 rabbits each.

\subsection{Animals and Management}

Rabbits in G1 were fed the basal diet, whereas those in G2, G3 and G4 were fed the same diet with REO at 0.25 , 0.5 and $0.75 \mathrm{~g} / \mathrm{kg}$ levels, respectively. The basal diet was formulated to contain $18.02 \%$ crude protein; 2512 $\mathrm{kcal} / \mathrm{kg}$ digestible energy; $15.30 \%$ crude fiber; $2.87 \%$ Ether extract; $1.30 \%$ Calcium; $0.71 \%$ Non-phytate P; $0.88 \%$ Lysine; $0.23 \%$ Methionine and $0.54 \%$ Meth. + Cyst as reported in our previous research (El-Gogary et al., 2018). Rabbits were housed in prepared one level battery confines $(50 \times 60 \mathrm{~cm})$ for the entire growing period which lasted two months (7-14 Wk).

\subsection{Measurements}

The growth performance of NZW growing rabbits during the entire experimental period was evaluated by live body weight (LBW), body weight gain (BWG), feed intake (FI) and feed conversion ratio (FCR). BWG, FI and FCR were determined on a replicate group basis.

\subsubsection{Carcass Characteristics}

At the termination of study (14 weeks of age), three rabbits per group, whose LBW were around the average weight of their respective group, were chosen for slaughter test. The rabbits were individually weighed, immediately sacrificed and reweighed after complete bleeding. Their carcasses were skinned and then eviscerated. Records on weights of carcasses and giblets (including liver, kidney, heart and lungs) were maintained.

\subsection{Blood Biochemical Constituents}

Blood samples from slaughtered rabbits (3/group) were collected in heparinized glass tubes, centrifuged at 3000 rpm for $15 \mathrm{~m}$, at that point plasma was maintained at $-18^{\circ} \mathrm{C}$ for later investigation. Blood glucose was instantly estimated. Plasma biochemical constituents (total cholesterol (Chol), triglycerides (TG), high density lipoprotein (HDL-C), low density lipoprotein (LDL-C), total antioxidant capacity (TAC) and malondialdehyde (MDA) were also measured. Testosterone assay was done by radioinmmunoassay (RIA) and immunoglobulins (IgG, IgA and IgM) were determined by ELISA technique.

\subsection{Statistical Analysis}

A completely randomized design was used in this study. A replicate group of three rabbits was used as an experimental unit. Data were statistically analyzed by means of one-way analysis of variance (SAS, 2006). Significant differences among means of different variables were identified by using Duncan's new multiple range test (Duncan, 1955).

\section{Results and Discussion}

\subsection{Growth Performance and Carcass Yield}

Results revealed that dietary supplementation with REO did not affect LBW and FI of rabbits during the whole experimental period and BWG and FCR at the starter stage (Table 1). However, both BWG and FCR were affected significantly by treatments during the finisher period (7-14 Wk). These results are in agreement with those reported by Erdelyi et al. (2008) and Cardinali et al. (2015) who found that dietary supplementation with $0.015 \mathrm{~g} / \mathrm{kg}$ REO had no effect on performance of growing rabbits. Furthermore, feed conversion ratio was improved by adding rosemary essential oil for the growing pigs (Yan et al., 2010). Other authors have suggested that essential oils can improve growth performance by enhacing feed intake and/or stimulating the secretion of digestive enzymes leading to an improvement in nutrient digestion and the rate of digesta passage within the gut 
(Bento et al., 2013; Jamroz et al., 2005; Salam et al., 2002).

Table 1. Effect of Rosemary supplementation on performance of NZW rabbits at different ages

\begin{tabular}{|c|c|c|c|c|c|c|c|c|c|}
\hline \multirow{2}{*}{ Groups } & \multicolumn{3}{|c|}{ LBW (Kg) } & \multicolumn{2}{|c|}{ BWG (Kg) } & \multicolumn{2}{|c|}{ FI (Kg) } & \multicolumn{2}{|c|}{ FCR } \\
\hline & 7 & $7-10$ & $7-14$ & $7-10$ & $7-14$ & $7-10$ & $7-14$ & $7-10$ & $7-14$ \\
\hline & -----. & ------ & - & --- & ------ V & 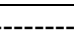 & --1-- & ----- & ----- \\
\hline G1 & 0.95 & 1.62 & 2.14 & 0.67 & $1.18^{\mathrm{a}}$ & 1.96 & 4.33 & 2.95 & $3.67^{\mathrm{b}}$ \\
\hline G2 & 0.98 & 1.57 & 2.03 & 0.59 & $1.05^{\mathrm{b}}$ & 1.95 & 4.26 & 3.33 & $4.08^{\mathrm{a}}$ \\
\hline G3 & 0.97 & 1.58 & 2.10 & 0.60 & $1.13^{\mathrm{ab}}$ & 2.00 & 4.30 & 3.32 & $3.82^{\mathrm{ab}}$ \\
\hline G4 & 0.97 & 1.53 & 2.04 & 0.57 & $1.07^{\mathrm{b}}$ & 1.93 & 4.27 & 3.51 & $3.99^{\mathrm{ab}}$ \\
\hline SEM & 0.02 & 0.04 & 0.03 & 0.03 & 0.03 & 0.02 & 0.07 & 0.23 & 0.12 \\
\hline Sig. & ns & ns & ns & ns & $*$ & ns & ns & ns & $*$ \\
\hline
\end{tabular}

Note $^{\text {a-b }}$ : Means in a similar section with various superscripts contrast altogether $(\mathrm{P} \leq 0.05)$.

The impacts of REO supplementation on carcass traits of rabbits at 14 weeks of age are presented in Table 2. It is clear from the results that carcass, kidneys and lungs weights were not affected significantly by different treatments. However, liver and heart weights were significantly heavier in treated groups compared by G1. This was reflected in the giblets weight (liver, heart, kidney and lungs) as it is a function of these organs. Of interest the observed increase in testes weight of treated compared with control rabbits which may reflect an androgenic stimulatory effect of REO on testes development. This holds true as plasma testosterone concentration was significantly increased in treated rabbits as will be discussed later. These outcomes are in concurrence with Cardinali et al. (2012) who found that carcass yield were not significantly influenced by dietary rosemary extract supplementation. In this context, Bento et al. (2013) found no adverse effect of essential oil on the carcass yield (breast and dressing percentages) and meat sensory quality in broiler chickens.

Table 2. Impact of Rosemary oil supplementation on carcass traits of NZW growing rabbits at marketing age

\begin{tabular}{|c|c|c|c|c|c|c|c|c|c|}
\hline Groups & LBW & Carcass & Liver & Heart & Kidney & Head & Lungs & Giblets & Testes \\
\hline & \multicolumn{9}{|c|}{---------- kg ---------- } \\
\hline G1 & 2.23 & 1.31 & $74.95^{\mathrm{b}}$ & $5.63^{\mathrm{b}}$ & 17.47 & 93.98 & 19.03 & 117.10 & $6.47^{\mathrm{b}}$ \\
\hline G2 & 2.57 & 1.31 & $93.33^{\mathrm{a}}$ & $8.30^{\mathrm{a}}$ & 16.93 & 108.10 & 14.77 & 133.33 & $7.60^{\mathrm{ab}}$ \\
\hline G3 & 2.23 & 1.30 & $81.20^{\mathrm{ab}}$ & $8.29^{\mathrm{a}}$ & 17.20 & 96.66 & 15.47 & 122.16 & $8.43^{\mathrm{a}}$ \\
\hline G4 & 2.55 & 1.35 & $82.00^{\mathrm{ab}}$ & $8.77^{\mathrm{a}}$ & 18.33 & 98.73 & 16.73 & 125.83 & $8.30^{\mathrm{a}}$ \\
\hline SEM & 0.13 & 0.21 & 4.47 & 0.62 & 1.16 & 4.37 & 1.75 & 4.99 & 0.53 \\
\hline Sig. & ns & ns & $*$ & $*$ & ns & ns & ns & ns & $*$ \\
\hline
\end{tabular}

Note. ${ }^{\mathrm{a}-\mathrm{b}}:$ Means in a similar section with various superscripts contrast altogether $(\mathrm{P} \leq 0.05)$.

\subsection{Blood Constituents and Immune Response}

The response of blood parameter to REO supplementation are summarized in Table 3. Blood glucose concentration was not significantly differ than that of the control group. These results are in agreement with Al-Jamal and Algadi (2011) who found that rosemary leaf extract did not affect plasma glucose level of rats. In fact, some flavonoids have anti-diabetic properties in term of improving glucose utilization and oxidative metabolism of diabetic states. Similarly, REO has no significant influence on plasma cholesterol, triglyceride and LDL-C, although the treated groups had reduced lipids profiles compared with the control. Whereas, rabbits of the G3 group had higher $(\mathrm{p}<0.05)$ HDL-C level than the other groups. These results agreed with the previous studies, in rats, which reported an increase in HDL-C without effects on plasma lipid profile (Al-Jamal \& Algadi, 2011). Also, the hypolipidemic potential of rosemary may be an indicator of progressive metabolic control of on mechanisms involved in elimination of lipids from the body (Kono et al., 1992; Naidua \& Thippeswamy, 2002; Devi \& Sharma, 2004). Yasser et al. (2010) agree with our study that cholesteryl ester hydrolase (CEH) would be the common link between the two metabolic effects. The role of CEH is to convert cholesteryl esters to free cholesterol for steroid hormone production. As well as, carnosic or rosmarinic acids (derived from rosemary) inhibited LDL-C oxidation in a dose-dependent manner (Fuhrman et al., 2000).

The results related to humoral immunity system of rabbits showed no significant influence of REO on IgG and 
IgM but, rabbits of the G3 group had the best response as IgA was significantly higher than the other groups. These results come in accordance with that obtained in the studies of Elnaggar et al (2016); Ghozlan et al. (2017) who found that the addition of rosemary to the basal diet had significantly improved serum immunoglobulins. Table 3 showed the impact of different doses of REO administration on plasma antioxidant status. It is of great interest to note that added dietary REO significantly increased TAC in the treated rabbits compared to the control group but the best response was achieved by rabbits fed $0.5 \mathrm{~g} / \mathrm{kg}$ REO in their diet. In a similar way, MDA was significantly lower in rabbits recieved the REO-containing diets compared with their control counterparts. These beneficial effects of REO may be attributable to the antioxidant properties of REO. These results are in agreement with Attia et al. (2017), who found that TAC were significantly increased in response to feeding rosemary leaves $(5 \mathrm{~g} / \mathrm{kg}$ diet $)$ in male rabbits. In addition, essential oils can affect lipid metabolism in animal tissues by increasing the antioxidative enzymes activity and by preventing the production of reactive oxygen species and off-flavors deriving from the peroxidation of polyunsaturated fatty acids (Miguel, 2010). On the other hand, our results are in agreement with those of Ugochukm et al. (2003), Afahari et al. (2007), and Bakrel et al. (2008) who observed that rosemary extract level $(200 \mathrm{mg} / \mathrm{kg})$ significantly reduced the level of serum MDA. It is generally accepted that quality of animal products is generally improved in response to added dietary supplementation of REO for animals. The REO are rich sources of natural antioxidants, such as the phenolic compounds, and due to their high redox properties and chemical structure they have the ability to neutralize the free radicals produced (Zheng \& Wang, 2001).

Table 3. Influence of rosemary supplementation on plasma total lipids, cholesterol, triglycerides, HDL-C and LDL-C in 14-week-old NZW growing rabbits

\begin{tabular}{|c|c|c|c|c|c|c|c|c|c|c|c|}
\hline Groups & Glucose & Chol. & TG & LDL-C & HDL-C & $\mathrm{IgG}$ & $\operatorname{IgA}$ & $\operatorname{IgM}$ & MDA & TAC & Testosterone \\
\hline & ----- & --- & $\cdots$ & --------- 1 1 & ng/dl ---- & -------- & & --------- & \multicolumn{2}{|c|}{---- nmol/ml ---- } & --- ng/ml --- \\
\hline G1 & 288.00 & 77.27 & 51.57 & 47.42 & $19.53^{\mathrm{ab}}$ & 515.77 & $159.50^{\mathrm{b}}$ & 133.03 & $30.57^{\mathrm{a}}$ & $1.10^{\mathrm{b}}$ & $2.47^{\mathrm{c}}$ \\
\hline $\mathrm{G} 2$ & 288.00 & 67.47 & 46.40 & 40.25 & $17.93^{\mathrm{b}}$ & 533.00 & $165.33^{\mathrm{ab}}$ & 142.37 & $26.73^{\mathrm{ab}}$ & $1.26^{\mathrm{ab}}$ & $3.44^{\mathrm{ab}}$ \\
\hline G3 & 288.67 & 69.33 & 47.17 & 37.90 & $22.00^{\mathrm{b}}$ & 578.93 & $191.37^{\mathrm{a}}$ & 156.97 & $20.30^{\mathrm{b}}$ & $1.41^{\mathrm{a}}$ & $3.67^{\mathrm{a}}$ \\
\hline G4 & 291.33 & 73.83 & 52.47 & 44.07 & $19.27^{\mathrm{ab}}$ & 523.97 & $161.93^{b}$ & 138.43 & $28.03^{\mathrm{ab}}$ & $1.17^{\mathrm{b}}$ & $3.31^{\mathrm{b}}$ \\
\hline SEM & 2.29 & 3.87 & 2.96 & 3.10 & 1.08 & 26.37 & 8.54 & 7.62 & 2.33 & 0.06 & 0.01 \\
\hline Sig. & ns & ns & ns & ns & $*$ & ns & $*$ & ns & $*$ & $*$ & $* * *$ \\
\hline
\end{tabular}

Note. ${ }^{\text {a-b-c }}:$ Means in a similar section with various superscripts contrast altogether $(\mathrm{P} \leq 0.05)$.

In fact, MDA is a product of lipid peroxidation and it is used as an indicator of cell membrance injury. It is generally accepted that an inverse relation exists between concentration of MDA and HDL-C cholesterol. Our results support this knowledge. A significant increase in testosterone level (in dose dependent manner) is due to REO compared with the control group. These results are in agreement with other the findings of Attia et al. (2017), who found that dietary rosemary leaves-fed groups showed significantly higher blood serum testosterone than the control group. As long as, lipid peroxidation and reactive oxygen species are potentially important mediators in testicular physiology (Peltola et al., 1996), the testis tissue is highly susceptible to oxidative stress because testicular membranes are highly rich in polyunsaturated fatty acids (Chainy et al., 1997). In fact, rosemary extract (carnosic or rosmarinic acids) has been targeting the hormone sensitive lipase (is also called cholesteryl ester hydrolase) which can convert cholesteryl esters to free cholesterol for the synthesis of steroid hormones including testosterone (Fuhrman et al., 2000).

\section{Conclusion}

Based on the present results, it can be concluded that dietary supplementation with rosemary essential oil can enhance the efficiency of feed utilization, and immune status of rabbits. In addition, supplemental REO can induce a beneficial effect on the lipid profile and oxidative status and may improve the subsequent reproductive performance of rabbits. The REO can safely be used in diets of growing rabbits, since it has no adverse effects on their growth performance or carcass characteristics.

\section{References}

Afshari, A. T., Shirpoor, A., Farshid, A., Saadatian, R., Rasmi, Y., Saboory, E., ... Allameh, A. (2007). The effect of ginger on diabetic nephropathy, plasma antioxidant capacity and lipid peroxidation in rats. Food Chemistry, 101, 148-153. https://doi.org/10.1016/j.foodchem.2006.01.013 
Al-Jamal, A., \& Alqadi, T. (2011). Effects of Rosemary (Rosmarinus officinalis) on Lipid Profile of Diabetic Rats. Jordan Journal of Biological Sciences, 4(4), 199-204.

Arouma, O. I., Soencer, J. P., Rossi, R., Aeschbach, R., Khan, A., Mahmood, N., ... Halliwell, B. (1996). An evaluation of antioxidant and antiviral action of extracts of rosemary and provencal herbs. Food Chem. Toxicol., 34, 449-456. https://doi.org/10.1016/0278-6915(96)00004-X

Attia, Y. A., Hamed, R. S., Bovera, F., Abd El-Hamid, A. E., Al-Harthi, M. A., \& Shahb, H. A. (2017). Semen quality, antioxidant status and reproductive performance of rabbits bucks fed milk thistle seeds and rosemary leaves. Animal Reproduction Science, 184, 178-186. https://doi.org/10.1016/j.anireprosci.2017. 07.014

Bakirel, T., Bakirel, U., Keleş, O. U., Ulgen, S. G., \& Yardibi, H. (2008). In vivo assessment of antidiabetic and antioxidant activities of rosemary (Rosmarinus officinalis) in alloxan-diabetic rabbits. Journal of Ethnopharmacology, 116, 64-73. https://doi.org/10.1016/j.jep.2007.10.039

Bento, M. H. L., Ouwehand, A. C., Tiihonen, K., Lahtinen, S., Nurminen, P., Saarinen, M. T., ... Fischer, J. (2013). Essential oils and their use in animal feeds for monogastric animals - Effects on feed quality, gut microbiota, growth performance and food safety: A review. Veterinarni Medicina, 58(9), 449-458. https://doi.org/10.17221/7029-VETMED

Cardinali, R., Cullere, M., Dal Bosco, A., Mugnai, C., Ruggeri, S., Mattioli, S., ... DalleZotte, A. (2015). Oregano, rosemary and vitamin E dietary supplementation in growing rabbits: Effect on growth performance, carcass traits, bone development and meat chemical composition. Livestock Science, 175, 83-89. https://doi.org/10.1016/j.livsci.2015.02.010

Cardinali, R., Dal Bosco, A., Mugnai, C., Mattioli, S., Ruggeri, S., Dalle Zotte, A., ... Castellini, C. (2012). Effect of different dietary aromatic essences on meat quality of rabbit. Proceedings 10th World Rabbit Congress, September 3-6, Sharm El-Sheikh, Egypt (pp. 925-929). World Rabbit Science Association.

Chainy, G. B. N., Samantaray, S., \& Samanta, L. (1997). Testosterone-induced changes in testicular antioxidant system. Andrologia, 29, 343-349. https://doi.org/10.1111/j.1439-0272.1997.tb00328.x

Cullen, S. P., Monahan, F. J., Callan, J. J., \& O’Doherty, J. V. (2005). The effect of dietary garlic and rosemary on grower-finisher pig performance and sensory characteristics of pork. Irish J Agric Food Res, 44, 57-67.

Cuppett, S. L., \& Hall, C. A. (1998). Antioxidant activity of Labiatae. Adv. Food Nutr. Res., 42, 245-271. https://doi.org/10.1016/S1043-4526(08)60097-2

Dal Bosco, A., Castellini, C., \& Cardinali, R. (2005). Effect of dietary administration of rosemary extract on the oxidative stability of pigeon meat. Ital. J. Food Sci., 4, 419-426.

Devi, R., \& Sharma, D. K. (2004). Hypolipidemic effect of different extracts of Clerodendron colebrookianum Walp in normal and high-fat diet fed rats. $J$ Ethnopharmacol, 90, 63-68. https://doi.org/10.1016/ j.jep.2003.09.022

El-Gogary, M. R., Mansour, A. M., \& El-Said, E. A. (2018). Blood Biochemical and Immunological Responses to Garlic Oil Administration in Growing Rabbits Diet. J. of Agric. Sci., 10(1), 217-224. https://doi.org/10.5539/jas.v10n1p217

ELnaggar, A. S., Abdel-Latif, M. A., El-Kelawy, M. I., \& Abd ELHamid, H. S. (2016). Productive, physiological, and immunological effects of rosemary leaves meal (Rosemarinus officinalis) supplementing to broiler diet. Egypt. Poult. Sci., 36(III), 859-873.

Erdelyi, M., Matics, Z., Gerencsér, Z., Princz, Z., Szendrö, Z., \& Mézes, M. (2008). Study of the effect of rosemary (Rosmarinus officinalis) and garlic (Allium sativum) essential oils on the performance of rabbits (pp. 649-654). In 9th World Rabbit Congress, June 10-13, Verona, Italy.

Fuhrman, B., Volkova, N., Rosenblat, M., \& Aviram, M. (2000). Lycopene synergistically inhibits LDL oxidation in combination with vitamin E, glabridin, rosmarinic acid, carnosic acid, or garlic. Antioxid Redox Signal, 2, 491-506. https://doi.org/10.1089/15230860050192279

Ghozlan, S. A., El-Far, A. H., Sadek, K. M., Abourawash, A. A., \& Abdel-Latif, M. A. (2016). Effect of Rosemary (Rosmarinus officinalis) Dietary Supplementation in Broiler Chickens Concerning immunity, Antioxidant Status, and Performance. Alexandria Journal of Veterinary Sciences, 55(1), 152-161. https://doi.org/10.5455/ajvs.275350 
Jamroz, D., Williczkiewicz, A., Wertelecki, T., Orda, J., \& Skorupinska, J. (2005). Use of active substances of plant origin in chicken diets based on maize and locally grown cereals. British Poultry Science, 46, 485-493. https://doi.org/10.1080/00071660500191056

Jones, F. A. (1996). Herbs-useful plants. Their role in history and today. Eur J Gastroenterol Hepatol, 8, 1227-1231. https://doi.org/10.1097/00042737-199612000-00018

Kadri, A., Zarai, Z., Ben Chobba, I., Bekir, A., Gharsallah, N., Damak, M., \& Gdoura, R. (2011). Chemical constituents and antioxidant properties of Rosmarinus officinalis L. essential oil cultivated from South-Western Tunisia. J Med Plants Res, 5, 5999-6004.

Koné, A. P., Cinq-Mars, D., Desjardins, Y., Guay, F., Gosselin, A., \& Saucier, L. (2016). Effects of plant extracts and essential oils as feed supplements on quality and microbial traits of rabbit meat. World Rabbit Sci., 24, 107-119. https://doi.org/10.4995/wrs.2016.3665

Kono, S., Shinchi, K., Ikeda, N., Yanai, F., \& Imanishi, K. (1992). Green tea consumption and serum lipid profiles: A cross-sectional study in northern Kyushu, Japan. Prev Med, 21, 526-531. https://doi.org/ 10.1016/0091-7435(92)90060-U

Lis-Balchin, M., \& Deans, S. G. (1997). Bioactivity of selected essential oils against Listeria monocytogenes. $J$ Appl Microbiol, 84, 538-544. https://doi.org/10.1046/j.1365-2672.1997.00153.x

Miguel, M. G. (2010). Antioxidant and anti-inflammatory activities of essential oils: A short review. Molecules, 15, 9252-9287. https://doi.org/10.3390/molecules 15129252

Moreno, S., Scheyer, T., Romano, C. S., \& Vojnov, A. A. (2006). Antioxidant and antibacterial activities of rosemary extracts linked to their polyphenol composition. Free Radic Res, 40, 223-231. https://doi.org/ $10.1080 / 10715760500473834$

Myers, G. L., Cooper, G. R., Henderson, L. O., Hassemer, D. J., \& Kimberly, M. (1994). Standardization of lipid and lipoprotein Measurements. In N. Rifai, \& G. R. Warnick (Eds.), Laboratory Measurement of Lipid and Lipoproteins and Apolipoproteins (pp. 177-205). AACC Press, Washington, DC, USA.

Naidu, K. A., \& Thippeswamy, N. B. (2002). Inhibition of human low density lipoprotein oxidation by active principles from spices. Mol Cell Biochem, 229, 19-23. https://doi.org/10.1023/A:1017930708099

Ngo, S. N., Williams, D. B., \& Head, R. J. (2011). Rosemary and cancer prevention: Preclinical perspectives. Crit Rev Food Sci Nutr, 51, 946-954. https://doi.org/10.1080/10408398.2010.490883

Paolicchi, A., Pezzini, A., Saviozzi, M., Piaggi, S., Andreuccetti, M., Chieli, E., ... Casini, A. F. (1996). Localization of a GSH-dependent dehydroascorbate reductase in rat tissues and subcellular fractions. Arch Biochem Biophys, 333, 489-495. https://doi.org/10.1006/abbi.1996.0419

Peng, Y., Yuan, J., Liu, F., \& Ye, J. (2005). Determination of active components in rosemary by capillary electrophoresis with electrochemical detection. J. Pharmaceutical Biomed. Analysis, 39, 431-437. https://doi.org/10.1016/j.jpba.2005.03.033

Rašković, A., Milanović, I., Pavlović, N., Ćebović, T., Vukmirović, S., \& Mikov, M. (2014). Antioxidant activity of rosemary (Rosmarinus officinalis L.) essential oil and its hepatoprotective Potential. International Society for Complementary Medicine Research, 14, 225. https://doi.org/10.1186/1472-6882-14-225

Sahar, T. A., Hafez, A. S., Hassan, M. A., \& Mansour, M. K. (2011). Influence of Rosemary Extract on Immune Responses and Oxidative Stress in Mice Intoxicated by Aflatoxins. Nature and Science, 9(10), 54-63.

Salam, O. M., Nada, S. A., \& Arbid, M. S. (2002). The effect of ginseng on bile-pancreatic secretion in the rat. Increase in proteins and inhibition of total lipids and cholesterol secretion. Pharmacological Research, 45, 349-353. https://doi.org/10.1006/phrs.2002.0961

Santana-Méridas, O., Polissiou, M., Izquierdo-Melero, M. E., Astraka, K., Tarantilis, P. A., Herraiz-Peñalver, D., \& Sánchez-Vioque, R. (2014). Polyphenol composition, antioxidant and bioplaguicide activities of the solid residue from hydrodistillation of Rosmarinus officinalis L. Industrial Crops and Products, 59, 125-34. https://doi.org/10.1016/j.indcrop.2014.05.008

SAS. (2006). Statistical Analysis System, SAS User's Guide. Statistics SAS institute Inc., Cary, NC, USA.

Simitzis, P. E., \& Deligeorgis, S. G. (2011). The effects of natural antioxidants dietary supplementation on the properties of farm animal products. Animal Feed: Types, Nutrition, Safety (pp. 155-168). Nova Science Publishers, Inc.: New York, NY, USA. 
Teixeira, B., Marques, A., Ramos, C., Neng, N. R., Nogueira, J. M. F., Saraiva, J. A., \& Nunes, M. L. (2013). Chemical composition and antibacterial and antioxidant properties of commercial essential oils. Ind Crop Prod, 43, 587-595. https://doi.org/10.1016/j.indcrop.2012.07.069

Ugochukwu, N. H., Babady, N. E., Cobourne, M., \& Gasset, S. R. (2003). The effect Gongronema latifolium extract on serum lipid profile and oxidative stress in hepatocytes of diabetic rats. Journal of Bioscience, 28, 1-5. https://doi.org/10.1007/BF02970124

Yan, L., Wang, J. P., Kim, H. J., Meng, Q. W., Ao, X., Hong, S. M., \& Kim, I. H. (2010). Influence of essential oil supplementation and diets with different nutrient densities on growth performance, nutrient digestibility, blood characteristics, meat quality and faecal noxious gas content in grower-finisher pigs. Livest. Sci., 128, 115-122. https://doi.org/10.1016/j.livsci.2009.11.008

Yasser, B., Ala, I., Mohammad, M., Mohammad, H., Khalid, T., Hatim, A., .. Bashar, A. (2010). Inhibition of hormone sensitive lipase and pancreatic lipase by Rosmarinus officinalis extract and selected phenolic constituents. J. of Med. Plants Res., 4(21), 2235-2242.

Zheng, W., \& Wang, S. Y. (2001). Antioxidant activity and phenolic compounds in selected herbs. J. Agric. Food Chem., 49, 5165-5170. https://doi.org/10.1021/jf010697n

\section{Copyrights}

Copyright for this article is retained by the author(s), with first publication rights granted to the journal.

This is an open-access article distributed under the terms and conditions of the Creative Commons Attribution license (http://creativecommons.org/licenses/by/4.0/). 